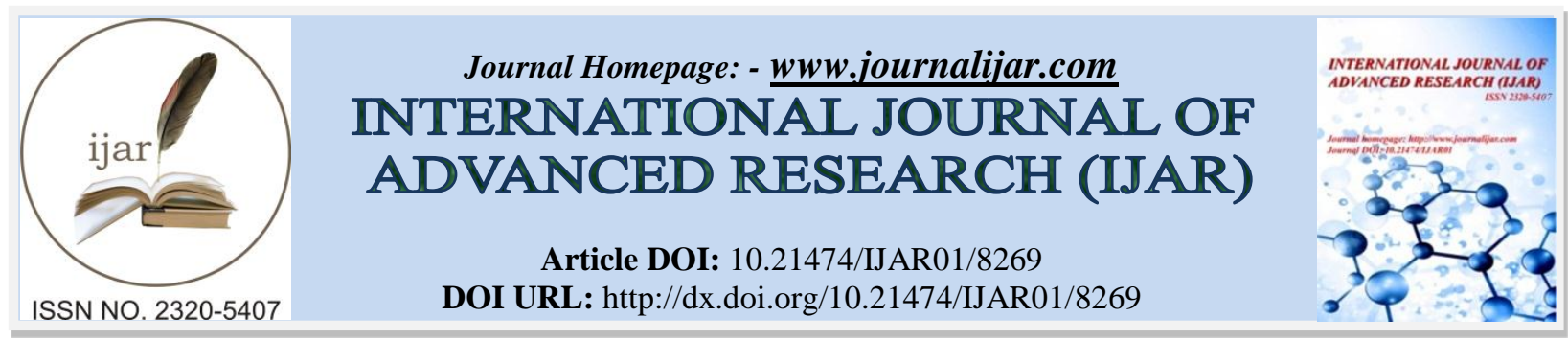

RESEARCH ARTICLE

\title{
LEADERSHIP AND EDUCATION AFFECT ON SOLDIERS' PERFORMANCE IN SUPPORTING NATIONAL DEFENSE (STUDY IN AIR DEFENSE ARTILLERY BATTALION 2/2/K MALANG).
}

1. master student of brawijaya university

2. postgraduate lecturer of brawijaya university.

3. postgraduate lecturer of wisnu wardhana university.

\section{Manuscript Info}

\section{Manuscript History}

Received: 20 October 2018

Final Accepted: 22 November 2018

Published: December 2018

Keywords:

Leadership, Education, Performance.

\begin{abstract}
Performance in an organization is an important asset that must be maintained because it is very necessary in an effort to realize the main tasks of the organization. One approach in an effort to improve performance can be done through the application of appropriate leadership and education. Leadership is needed by leaders in order to preserve their organizations to achieve goals. While education is very necessary in order to support the achievement of basic tasks effectively and efficiently. The research was carried out in the Unit because the Air Defense Artillery Battalion 2/2/K Malang was one of the best units in the Indonesian Army. This research is quantitative research with primary data obtained from questionnaires filled out by respondents. The number of respondents was 85 people selected from various parts of the Air Defense Artillery Battalion 2/2 / K Malang. The purpose of this study is to analyze and look for the influence between leadership and education on performance. And the results of this study are expected to be useful in enriching theories related to human resource management and beneficial for Air Defense Artillery Battalion 2/2 / K in Malang in determining future policies so as to optimize the performance of their soldiers.
\end{abstract}

Copy Right, IJAR, 2018,. All rights reserved.

\section{Introduction:-}

In general, leadership is a science that comprehends comprehensively about how to direct, influence and supervise other people to do tasks according to the planned order. In particular, in the perspective of the Indonesian Army Forces, the leadership concept that was applied in the Indonesian Army Forces was field leadership which named by leadership that not only sat behind a desk but also had to be able to blend and work together in the field or task field directly. In this case, field leadership is an integration of 5 (five) leader typologies that must be realized in real terms, such being as fathers, coaches, friends, teachers and commanders.

Regarding to education, it is also important in influencing performance. The importance of education cannot be denied by anyone. Today, Indonesia continues to increase education subsidies so that people enjoy the education. Awareness that the nation and the state will not advance without education is an indication of public concern for

\section{Corresponding Author:-Rudi ariyanto.}

Address:-master student of brawijaya university. 
education. Many views of thinkers about the meaning of education, they see education in various perspectives so that the meaning of education depends on the perspective used.

In general, education is a conscious and systematic effort to achieve a standard of living or for better progress. An explanation of leadership and education above cannot be separated from performance due to the implementation of leadership and education in order to optimize performance. In order to achieve maximum performance, the work carried out must refer to the desire to achieve certain goals. Clarity of purpose in a job will determine the ways, methods, techniques and strategies used to do a job. Accumulation of various ways, methods, techniques and strategies that are prepared and used by someone to work to achieve the desired goal is a picture of one's performance.

\section{Research problem.}

Based on the description of the background above, a number of related Research problem are obtained including:

1. What is the influence of leadership on the performance of Air Defense Artillery Battalion 2/2/K in Malang?

2. What is the effect of education on the performance of Air Defense Artillery Battalion $2 / 2 / \mathrm{K}$ in Malang?

3. What is the influence of both leadership and education on the performance of Air Defense Artillery Battalion $2 / 2 / \mathrm{K}$ in Malang?

\section{Hypothesis}

Based on the research problem above, several hypothesis related to this research can be drawn including:

1. Leadership has a positive and significant effect on the performance of Air Defense Artillery Battalion $2 / 2 / \mathrm{K}$ in Malang.

1. Ho: Leadership does not affect the performance of soldiers.

2. Hi: Leadership affects the performance of soldiers.

2. Education has a positive and significant effect on the performance of Air Defense Artillery Battalion $2 / 2 / \mathrm{K}$ in Malang.

1. Ho: Education does not affect the performance of soldiers.

2. Hi: Education affects the performance of soldiers.

3. Both of leadership and education have a positive and significant effect on the performance of Air Defense Artillery Battalion 2/2/K in Malang.

1. Ho: Leadership and education do not affect the performance of soldiers.

2. Hi: Leadership and education affect the performance of soldiers.

\section{Research Methods:-}

\section{Time and Location of Research:-}

This research was conducted in Batalyon Arhanud 2/2/K Malang. The main reason for choosing the location is because this institution is one aligned units Arhanud TNI AD, it has 4 types of Alutsista defense equipment, it has many achievements, and the population this units has various. While the time of study was began on October until November 2018.

\section{Research methods:-}

This research uses survey research, namely to find relationships between several variables.

\section{Sampling technique:-}

The sampling technique used in this study is the total sampling technique because the samples taken are all members of Batalyon Arhanud 2/2/K. The overall number of personal are 561 peoples and this research used 85 peoples.

\section{Data Retrieval Techniques:-}

Data collection techniques was used Questionnaire, Observation, Documentation and Interview. The data collected is in the form of answers to questions that have been prepared using the linkert scale 


\section{Data analysis technique:-}

This research uses quantitative analysis technique with descriptive analysis approach. Meanwhile, to test associative hypotheses or relationships if the data are in the form of intervals, then the moment product correlation and multiple correlation tests are used.

\section{Research Result And Discussion:-}

\section{Data Analysis:-}

\section{a. Validity Test}

Validity test was carried out on the questionnaire instrument to find out how far the correlation of items of questions / statements contained in the questionnaire to the total number of research variables. The formula used in calculating validity in this study is the Pearson Product Moment formula as follows:

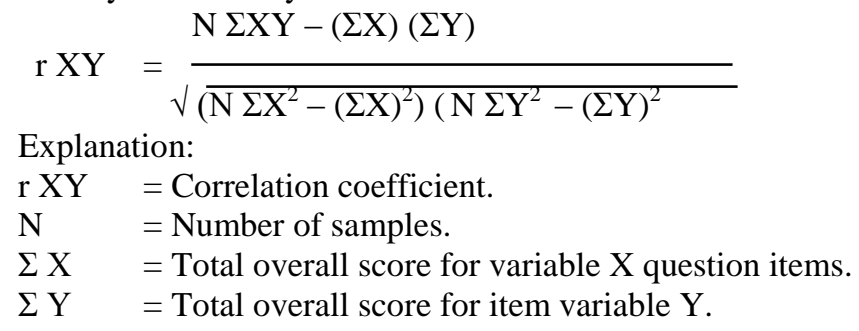

Based on the provisions of the formula, the criteria specified in determining whether a valid or not statement to be used as an instrument in this study are as follows:

1. If $r$ XY 30,3 , then the statement items are declared valid.

2. If $\mathrm{r} X Y<0.3$, then the statement items are declared invalid.

After obtaining data from the results of the questionnaire and then processing the data using the Pearson Product Moment formula, the following results are obtained:

\begin{tabular}{|c|c|c|c|}
\hline No & r Count & r Critical & Result \\
\hline r1y & 0,72 & 0,3 & Valid \\
\hline$r 2 y$ & 0,56 & 0,3 & Valid \\
\hline r3y & 0,81 & 0,3 & Valid \\
\hline $\mathrm{r} 4 \mathrm{y}$ & 0,56 & 0,3 & Valid \\
\hline r5y & 0,59 & 0,3 & Valid \\
\hline r6y & 0,70 & 0,3 & Valid \\
\hline r7y & 0,78 & 0,3 & Valid \\
\hline r8y & 0,80 & 0,3 & Valid \\
\hline r9y & 0,69 & 0,3 & Valid \\
\hline r10y & 0,56 & 0,3 & Valid \\
\hline r11y & 0,78 & 0,3 & Valid \\
\hline r12y & 0,59 & 0,3 & Valid \\
\hline r13y & 0,56 & 0,3 & Valid \\
\hline r14y & 0,73 & 0,3 & Valid \\
\hline $\mathrm{r} 16 \mathrm{y}$ & 0,72 & 0,3 & Valid \\
\hline $\mathrm{r} 17 \mathrm{y}$ & 0,57 & 0,3 & Valid \\
\hline r18y & 0,45 & 0,3 & Valid \\
\hline r19y & 0,72 & 0,3 & Valid \\
\hline $\mathrm{r} 20 \mathrm{y}$ & 0,59 & 0,3 & Valid \\
\hline $\mathrm{r} 21 \mathrm{y}$ & 0,50 & 0,3 & Valid \\
\hline $\mathrm{r} 22 \mathrm{y}$ & 0,70 & 0,3 & Valid \\
\hline $\mathrm{r} 23 \mathrm{y}$ & 0,56 & 0,3 & Valid \\
\hline $\mathrm{r} 24 \mathrm{y}$ & 0,75 & 0,3 & Valid \\
\hline $\mathrm{r} 25 \mathrm{y}$ & 0,43 & 0,3 & Valid \\
\hline $\mathrm{r} 26 \mathrm{y}$ & 0,76 & 0,3 & Valid \\
\hline r27y & 0,58 & 0,3 & Valid \\
\hline $\mathrm{r} 28 \mathrm{y}$ & 0,51 & 0,3 & Valid \\
\hline r29y & 0,61 & 0,3 & Valid \\
\hline r30y & 0,57 & 0,3 & Valid \\
\hline
\end{tabular}




\begin{tabular}{|l|l|l|l|}
\hline r32y & 0,56 & 0,3 & Valid \\
\hline r33y & 0,61 & 0,3 & Valid \\
\hline r34y & 0,48 & 0,3 & Valid \\
\hline r35y & 0,60 & 0,3 & Valid \\
\hline r36y & 0,3 & Valid \\
\hline r37y & 0,59 & 0,3 & Valid \\
\hline r38y & 0,56 & 0,3 & Valid \\
\hline r39y & 0,58 & 0,3 & Valid \\
\hline r40y & 0,59 & 0,3 & Valid \\
\hline r41y & 0,65 & 0,3 & Valid \\
\hline r42y & 0,48 & 0,3 & Valid \\
\hline r43y & 0,61 & 0,3 & Valid \\
\hline r44y & 0,54 & 0,3 & Valid \\
\hline r45y & 0,57 & 0,3 & Valid \\
\hline r46y & 0,61 & 0,3 & Valid \\
\hline r47y & 0,61 & 0,47 & Valid \\
\hline
\end{tabular}

Based on the results above, data obtained that the overall $\mathrm{r}$ count for leadership, education and performance variables is greater than $\mathrm{r}$ critical. This means that each item in the questionnaire used in this study is valid.

\section{Reliability Test}

Reliability test was performed on the questionnaire instrument to determine the reliability of the measuring instrument used in the study using the Cronbach Alpha formula. Based on the provisions of the formula, the criteria specified in determining whether a statement is reliable or not to be used as an instrument in this study are if it gives Cronbach Alpha values $r>0.60$. The Cronbach Alpha formula used in calculating reliability in this study is as follows:

$$
\mathrm{r}=\frac{\mathrm{k}}{\mathrm{k}-1}\left(\frac{\left.1-\Sigma \alpha \mathrm{b}^{2}\right)}{\alpha \mathrm{t}^{2}}\right)
$$

Explanation:

$\mathrm{r}=$ Instrument reliability.

$\mathrm{k} \quad=$ Number of questions.

$\alpha \mathrm{b} \quad=$ Variant overall score.

$\alpha \mathrm{t} \quad=$ Total variant.

After obtaining data from the results of the questionnaire then the data processing was performed using the Cronbach Alpha formula above, so that the following results were obtained:

\begin{tabular}{|l|l|l|l|}
\hline No & C Count & $r$ Critical & Result \\
\hline$r X_{1}$ & 1,062 & 0,6 & Reliable \\
\hline$r X_{2}$ & 1,111 & 0,6 & Reliable \\
\hline$r Y$ & 1,053 & 0,6 & Reliable \\
\hline
\end{tabular}

Based on the data above, the results show that the overall $\mathrm{r}$ counts for leadership, education and performance variables greater than 0.6. This means that each item in the questionnaire used in this study is reliable.

The Relationship between Leadership and Soldiers Performance

Calculation of leadership variable correlation with performance using the Product Moment correlation formula as follows:

$$
\begin{aligned}
\mathrm{rX}_{1} \mathrm{Y} & =\frac{\Sigma \mathrm{XY}}{\sqrt{\left(\overline{\left.\Sigma \mathrm{X}^{2}\right)\left(\Sigma \mathrm{Y}^{2}\right)}\right.}} \\
& =\frac{2.702,11}{\sqrt{5.718,89 \times 4.824,29}}
\end{aligned}
$$


$=0,51$

So there is a positive correlation of 0.51 between leadership variables with performance variables. Furthermore, it is necessary to find out about the level of significance, whether the price is significant or not. When using calculation with $r$ table for $n=85$ and error $5 \%$, then the value of $r$ table $=0,213$ while for the value of $r$ count $=0,51$. The Provision is if the calculated $r$ value is smaller than the $r$ table value, then Ho is accepted and Hi is rejected. But conversely if the value of $r$ count is greater than $r$ table $(r h>r t)$ then Hi is accepted. From the results it can be seen that the calculated $r$ value is greater than the $r$ table value so $\mathrm{Ha}$ is accepted, thus the 0.51 correlation is positive and significant.

\section{Relationship between Education and Soldier Performance}

Calculation of leadership variable correlation with performance using the Product Moment correlation formula as follows:

$$
\begin{aligned}
\mathrm{rX}_{2} \mathrm{Y} & =\frac{\sum \mathrm{X} \mathrm{Y}}{\sqrt{\left(\overline{\left.\sum \mathrm{X}^{2}\right)\left(\Sigma \mathrm{Y}^{2}\right)}\right.}} \\
& =\frac{1.034,52}{\sqrt{1.570,71 \times 4.824,29}} \\
& =0,38
\end{aligned}
$$

So there is a positive correlation of 0.38 between leadership variables with performance variables. For next, it is necessary to find out about the level of significance, whether the price is significant or not. When using calculation with $r$ table for $n=85$ and error $5 \%$, then obtained $r$ table $=0.213$ while for the value of $r$ count $=0.38$. The provisions is if $\mathrm{r}$ count value is smaller than $\mathrm{r}$ table value, then Ho is accepted and Hi is rejected But conversely if the value of $\mathrm{r}$ count is greater than $\mathrm{r}$ table $(\mathrm{r} \mathrm{h}>\mathrm{r} \mathrm{t}$ ) then $\mathrm{Hi}$ is accepted. From the results it can be seen that the value of $r$ count is greater than the value of $r$ table so $\mathrm{Ha}$ is accepted, thus the correlation of 0.38 is positive and significant.

\section{Relationship between Leadership and Education with Soldiers Performance}

The Calculation of correlation between both of leadership and education variables on the performance of soldiers on hypotheses used multiple correlation formula. But before calculating the correlation between leadership and education variables on performance variables, the correlation must be calculated among the independent variables, namely leadership and education. The correlation calculation uses the Product Moment correlation formula as follows:

$$
\begin{aligned}
\mathrm{rX}_{1} \mathrm{X}_{2} & =\frac{\sum X \mathrm{Y}}{\sqrt{\left(\overline{\left.\Sigma \mathrm{X}^{2}\right)\left(\Sigma \mathrm{Y}^{2}\right)}\right.}} \\
& =\frac{1.388,82}{\sqrt{5.718,89 \times 1.570,71}} \\
& =0,46
\end{aligned}
$$

After the results was obtained from the calculation of the correlation between 2 (two) independent variables above, then the results of the calculation of correlation are included in the multiple correlation formula. The correlation formula between variables is as follows:

\begin{tabular}{|c|c|c|c|}
\hline Var. & r Count & r Table & Result \\
\hline $\mathrm{r} \mathrm{X}_{1} \mathrm{Y}$ & 0,51 & 0,213 & Significant \\
\hline $\mathrm{r} \mathrm{X}_{2} \mathrm{Y}$ & 0,38 & 0,213 & Significant \\
\hline $\mathrm{r} \mathrm{X}_{1} \mathrm{X}_{2}$ & 0,46 & 0,213 & Significant \\
\hline
\end{tabular}


The calculation of the correlation variables of both leadership and education on performance using the multiple correlation formula are as follows:

$$
\begin{aligned}
R X_{1} X_{2} Y & =\sqrt{\frac{r^{2} x_{1} y+r^{2} x_{2} y-2 r x_{1} y r x_{2} y x_{1} x_{2}}{1-r^{2} x_{1} x_{2}}} \\
& =\sqrt{\frac{0,51^{2}+0,38^{2}-(0,51)(0,38)(0,46)}{1-0,46^{2}}} \\
& =0,535
\end{aligned}
$$

Then, there is a positive correlation between leadership and education with a performance of 0.535 . This relationship can be expressed qualitatively medium and the magnitude more than individual correlation between X1 and Y also X2 with Y. Correlation of 0.535 is only valid for the sample under the study. Whether the correlation coefficient can be generalized or not, the significance is must be tested. To test the significance used formula F. Calculation of significance of the correlation coefficient of leadership and education variables together on performance as follows:

$$
\begin{aligned}
\mathrm{F}_{\mathrm{h}} & =\frac{\mathrm{R}^{2} / \mathrm{k}}{\left(1-\mathrm{R}^{2}\right) /(\mathrm{n}-\mathrm{k}-1)} \\
& =\frac{0,535^{2} / 2}{\left(1-0,535^{2}\right) /(85-2-1)} \\
& =\frac{0,535^{2} / 2}{\left(1-0,535^{2}\right) /(85-2-1)} \\
& =16,441
\end{aligned}
$$

Based on the results of the calculation above using the formula $\mathrm{F}$, the results obtained for $\mathrm{F}_{\mathrm{h}}=16,441$. This price is then consulted with $\mathrm{F}$ table $\left(\mathrm{F}_{\mathrm{t}}\right)$, with the numerator $\mathrm{dk}=\mathrm{k}$ and the denominator $=(\mathrm{n}-\mathrm{k}-1)$ and the level of error set is $5 \%$. F table obtained is $F_{t}=3.11$. In this case the provisions apply if $F_{h}$ is greater than $F_{\text {t }}$, so the multiple correlation coefficients tested are significant, i.e. can be applied to the entire population. From the calculation above, it turns out that $F_{h}$ is greater than $\mathrm{Ft}(16,441>3,11)$ so it can be stated that the multiple correlation is significant and can be applied to the entire study population.

\section{Conclusions And Suggestions:-}

\section{Conclusions:-}

Based on the results of the data analysis process that has been collected in the study of the influence of leadership and education on the performance of soldiers in supporting national defense with studies in the Air Defense Artillery Battalion 2/2/K Malang, some conclusions can be drawn as follows:

1. The influence of leadership on the performance of Air Defense Artillery Battalion 2/2 / K soldiers in Malang is positive and significant. The positive effect is indicated by the results of the Product Moment correlation calculation of 0.51 . And for the correlation that is significant is indicated by the results of the calculation of the formula $\mathrm{t}$ of 4.839 where the value is greater than the table $\mathrm{t}$ is 2.00 .

2. The effect of education on the performance of Air Defense Artillery Battalion 2/2 / K soldiers in Malang is positive and significant. The positive effect is indicated by the results of the Product Moment correlation calculation of 0.38 . And for the correlation that is significant is indicated by the results of the calculation of the formula $t$ of 3.812 where the value is greater than the table $t$ is 2.00 . 
3. The influence of leadership and education on the performance of Air Defense Artillery Battalion $2 / 2 / \mathrm{K}$ in Malang is positive and significant. The positive effect is indicated by the results of the double correlation calculation of 0.535 . And for the correlation that is significant is indicated by the results of the calculation of the formula $\mathrm{F}$ of 16,441 where the value is greater than $\mathrm{F}$ table which is 3,11 .

\section{Suggestion:-}

By paying attention to the results of the analysis of the data obtained during the research, several things can be suggested as follows:

1. Air Defense Artillery Battalion Commander $2 / 2 / \mathrm{K}$ is requested to be able to hold debriefing or training on leadership for the subordinate elements of Commander because according to the results of this study, leadership can have a positive influence on improving member performance.

2. Air Defense Artillery Battalion Commander $2 / 2 / \mathrm{K}$ is requested to be able to provide the widest opportunity for its members in order to continue their education because according to the results of this study, education can have a positive influence on improving member performance.

\section{Bibliography:-}

1. Alma, Buchari. 2009. Kewirausahaan. Bandung: Alfabeta.

2. Amstrong, Michael. 2004. Performance Management. Yogyakarta: Tugu Publisher.

3. Arifin, Noor dan Komaruddin. 2009. Analisis Pengaruh Kepemimpinan, Kapabilitas, Komitmen terhadap Kinerja Anggota Satuan Komando Distrik Militer 0719 Jepara. Dalam Jurnal Dinamika Ekonomi dan Bisnis, Vol. 6, Nomor 2.

4. As'ad, Muhammad. 2005. Psikologi Industri. Yogyakarta: Liberty.

5. Azwar, Saifudin. 2012. Penyusunan Skala Psikologi. Yogyakarta: Pustaka Pelajar.

6. Basri, Hasan. 2009. Filsafat Pendidikan Islam. Bandung: Pustaka Setia.

7. Bastian, Indra. 2001. Akuntansi Sektor Publik. Yogyakarta: Badan Penerbit Fakultas Ekonomi UGM.

8. Brantas, 2009. Dasar-Dasar Manajemen. Bandung: Alfabeta.

9. Cooper, Donald R dan Schinder, Pamela S. 2007. Business Research Methods. Boston: McGraw-Hill.

10. Daft, Richard, L. 2003. Manajemen. Jakarta: Erlangga.

11. Daryanto dan Farid, Mohammad. 2013. Konsep Dasar Manajemen Pendidikan di Sekolah. Yogyakarta: Penerbit Gava Media.

12. Dewi, D. Ketut, Ratna dan Suwendra, I Wayan dan Yulianthini, Ni Nyoman. 2016. Pengaruh Tingkat Pendidikan dan Motivasi Kerja terhadap Kinerja Karyawan. Dalam e-Jurnal Bisma Universitas Pendidikan Ganesha Jurusan Manajemen, Vol. 4.

13. Fathurrahman, Pupuh. 2011. Dasar-Dasar Kependidikan. Bandung: Pustaka Setia.

14. Galton, Maurice dan Simon, Brian. Progress and Performance in the Primary Classroom. London: Routledge and Legan Paul.

15. Gomes, Faustino, Cardaso. Manajemen Sumber Daya Manusia. Yogyakarta: Andi Offset.

16. Griffin, Ricky, W. 2003. Manajemen. Jakarta: Erlangga.

17. Handoko, T. Hani. 2012. Manajemen Personalia dan Sumber Daya Manusia. Yogyakarta: BPFE.

18. Hasibuan, Malayu. 2012. Manajemen Sumber Daya Manusia. Jakarta: Bumi Aksara.

19. Instruksi Presiden No.9 Tahun 2016 tentang Revitalisasi Sekolah Menengah Kejuruan Dalam Rangka Peningkatan Kualitas Dan Daya Saing Sumber Daya Manusia Indonesia.

20. Kemhan Republik Indonesia. 2015. Buku Putih Pertahanan Indonesia. Jakarta.

21. King, Patricia. 2013. Performance Planning and Appraisal: A How-To Book for Manager. New York: McGrawHill Book Company.

22. Kusumo. 2009. Analisis Pengaruh Kepemimpinan Manajemen, Teknologi Informasi dan Struktur Organisasi terhadap Kinerja Perusahaan. Tesis Magister Manjemen, Program Studi Magister Manajemen Universitas Diponegoro, Semarang.

23. Mamahit, Rendry. 2013. Tingkat Pendidikan, Pelatihan dan Kepuasan Kerja Pengaruhnya terhadap Kinerja Pegawai di Badan Penanggulangan Bencana Provinsi Sulawesi Utara. Dalam Jurnal EMBA, Vol. 1, Nomor 4.

24. Priatna, Tedi. 2004. Reaktualisasi Paradigma Pendidikan Islam. Bandung: Pustaka Bani Quraisy.

25. Purnomo, Dwi, Helly dan Novianto, Louis. 2013. Seni Mengarahkan untuk Mendongkrak Kinerja. Jakarta: Gramedia Pustaka Utama.

26. Robbins, Stephen, P. 2003. Perilaku Organisasi. Jakarta: Indeks.

27. Ryacudu, Ryamizard, 2004. "Jenderal TNI Ryamizard Ryacudu Seorang Militer Sejati”. Gema Diponegoro, No. 95, Halaman 5, Novemeber 2004. 
28. Saebani, Beni, Ahmad dan Achdiyat, Hendra. 2009. Ilmu Pendidikan Islam Jilid 1. Bandung: Pustaka Setia.

29. Siagian, Sondang, P. 2015. Teori dan Praktek Kepemimpinan. Jakarta: Rineka Cipta.

30. Simamora, Henry. 2013. Manajemen Sumber Daya Manusia. Yogyakarta: STIE YKPN.

31. Sugiyono. 2018. Metode Penelitian Kuantitafif. Bandung: Alfabeta.

32. Suprihanto, John. 2012. Penilaian Kinerja dan Pengembangan Karyawan. Yogyakarta: BPFE.

33. Tika, Moch, Prabu. 2006. Budaya Organisasi dan Peningkatan Kinerja Perusahaan. Bandung: Bumi Aksara.

34. Uha, Ismail, Nawawi. 2017. Budaya Organisasi Kepemimpinan dan Kinerja. Depok: Kencana.

35. Undang-Undang Republik Indonesia No. 20 Tahun 2003 tentang Sistem Pendidikan Nasional.

36. Undang-Undang Republik Indonesia No.34 Tahun 2004 tentang Tentara Nasional Indonesia.

37. Yuniarti, Dwi dan Supriantoro, Erlian. 2014. Pengaruh Gaya Kepemimpinan dan Tingkat Pendidikan terhadap Kinerja Karyawan pada Direktorat Operasi/Produksi PT. X. Dalam Jurnal INDEPT, Vol. 4, Nomor 1. 